\title{
Citizenship as absolute space, citizenship as contingent trace
}

DOI:

10.1177/030437541003500403

\section{Document Version}

Final published version

Link to publication record in Manchester Research Explorer

\section{Citation for published version (APA):}

Ní Mhurchú, A. (2010). Citizenship as absolute space, citizenship as contingent trace. Alternatives: Local, Global, Political , 35(4), 373-400. https://doi.org/10.1177/030437541003500403

\section{Published in:}

Alternatives: Local, Global, Political

\section{Citing this paper}

Please note that where the full-text provided on Manchester Research Explorer is the Author Accepted Manuscript or Proof version this may differ from the final Published version. If citing, it is advised that you check and use the publisher's definitive version.

\section{General rights}

Copyright and moral rights for the publications made accessible in the Research Explorer are retained by the authors and/or other copyright owners and it is a condition of accessing publications that users recognise and abide by the legal requirements associated with these rights.

\section{Takedown policy}

If you believe that this document breaches copyright please refer to the University of Manchester's Takedown Procedures [http://man.ac.uk/04Y6Bo] or contact uml.scholarlycommunications@manchester.ac.uk providing relevant details, so we can investigate your claim.

\section{OPEN ACCESS}




\title{
Citizenship as Absolute Space, Citizenship as Contingent Trace
}

\begin{abstract}
Aoileann Ní Mhurchú*
Published in Alternatives: Local, Global, Political, Vol. 35, Issue.4, October - December, pp373-400

ABSTRACT

Using the distinction which Richard Ashley and Rob Walker drew in 1990 between two possible critical responses to crisis and the question of sovereignty, this paper argues that two strands of thought can be identified which each produce a different understanding of what it means to become a citizen in the context of migration. One strand articulates citizenship in terms of sovereign autonomous subjectivity and thus in terms of horizontal or territorial relations between here and there, us and them, inside and outside. The other strand (re)articulates citizenship in terms of ambiguous paradoxical subjectivity which challenges rather the modern framing of the politics of citizenship as necessarily needing to be conceptualized in terms of absolute space. This divergence is explored through the 2004 Irish Citizenship Referendum. The concept of citizenship as 'trace' is introduced in an attempt to capture how citizenship is reconceptualized differently in the second strand. It is argued that understanding this divergence is necessary in order to consider how classical conceptions of time and space are specifically integral to structures of sovereign power and how perspectives which take these as their starting point fail to account for the increasing emphasis on the nonsovereign manner in which citizenship is being experienced vis-à-vis migration.
\end{abstract}

Key words: citizenship; space; subjectivity; sovereignty; time; 2004 Irish Citizenship Referendum

\footnotetext{
* School of Law and Government, Dublin City University, Glasnevin, Dublin 9, Rep. of Ireland, (00353) 868647298, aoileann.nimhurchu@dcu.ie
} 


\section{INTRODUCTION}

Porous boundaries and multiple identities undermine ideas of cultural belonging as a necessary accompaniment to political membership. There are increasing numbers of citizens who do not belong...The solution must lie in a mode of citizenship that reconciles the pressures of globalization with the reality that states will continue for the foreseeable future, to exist as the most important political unit. - Stephen Castles and Alastair Davidson ${ }^{1}$

A growing number of people living in Europe do not seem to inhabit the social space which corresponds to the expansion of citizenship rights, that is 'civil society'. Rather, their lives are increasingly the targets of the technologies of governmentality which define what Partha Chatterjee has called the heterogeneous space of political society, and which often predate the nations-state...The postcolonial migratory movements of the present are in this sense a challenge not only to the borders of European citizenship, but also to the borders of our imagination. - Sandro Mezzadra $^{2}$

These two quotes reflect a growing disbelief within citizenship scholarship that the concept of citizenship can continue to be defined according to dominant ideals and practices of solidarity located in the nation-state given the challenges which migration poses to it. However, despite a shared recognition of a purported need to problematize how belonging has been located in a national statist community which assumes common history and culture of citizens, these two authors pose very different responses to the question itself of how a new 'politics' of citizenship should be theorized in relation to the issue of migration. In considering the growing inter- 
disciplinary concern with the challenge which migration poses to traditional notions of what it is to be a citizen, this paper sets out to explore this tension. It argues that two strands of thought can be identified which each produce a different understanding of what it means to be(come) 'citizen' in this context. In one this is articulated in terms of sovereign autonomous subjectivity and the notion of an us/them dualism is thereby maintained by continuing to frame "the tractable puzzles of modern politics...in terms of horizontal or territorial relations between self and world, self and other, this community here and that community there"3; in the other this is articulated in terms of ambiguous paradoxical subjectivity which collapses this us/them dualism and undermines the idea itself that modern politics can (only) be articulated in this way.

These strands of thought are not intended to be taken as analogous to clearly delineated and competing citizenship theories. Nor, is the implication here that all theorizations of citizenship, and therefore particular authors, necessarily fall neatly into one or the other of them. Rather, this distinction is being used here to explore a difference in approach (woven across and within citizenship studies) which exists in theorizing the question itself of what and where politics can be when it comes to citizenship and the question of how migration demands a radical retheorization of this. It will be suggested that in one strand the politics of citizenship (what 'citizen' can be) is conceptualized as that which is divided but can ultimately be reunited and therefore as extended in absolute space. In contrast to this, it will be pointed out that in the other it is reconceptualized in terms of contingent trace; as based upon disruptions and discontinuities in its own right and therefore figuring in indeterminate spaces which can only be "traced in the blur...or in mediation" 
TWO STRANDS OF THOUGHT: ALTERNATIVE RESPONSES TO CRISIS AND THE QUESTION OF SOVEREIGNTY

The quotation by Castles and Davidson above emphasizes a perceived need to continue to pose the question of citizenship vis-à-vis its relationship with the (sub/ supra or transnational) state. Although highlighting the challenges that migration places upon the dominant ideals and practices of solidarity conceptualized in terms of the state, it seeks nonetheless to understand this challenge in terms of how the state continues to define the parameters of solidarity in the twenty-first century. It is a response, in other words, to the rapidly increasing global phenomenon of migration which results in a call for a move away from the notion that 'genuine' citizenship is located (only) in sovereign territorial authority but towards a need to conceive of how state citizenship forms what Habermas calls "a continuum" with world citizenship. ${ }^{5}$ Here state sovereignty (conceptualized as the relationship between nationality, territory and statehood) is problematized by questioning the manner in which this has been historically conceptualized as the dominant mode of belonging. Alternative possibilities for conceptualizing solidarity outside of this particular nationalist framing are then emphasized by asking how individuals might be positioned vis-à-vis an inter-statist or trans-statist social or symbolic order. The implication here is that political possibility is extended by thinking about political life in terms of a continuum within and between modern territorial states. However, despite taking away the supposition of conflict, the politics of citizenship (the relationship between migration policies, and understandings of what it means to become 'citizen') continues to be conceptualized here in terms of "a form of inclusion that depends on a clear pattern of spatial exclusion". ${ }^{6}$ Instead of a world of aliens and citizens, what we are promised is a world in which belonging continues to be based on the notion of 
absolute spatial exclusion in the last instance; this is merely an exclusion which no longer involves treating the Other as enemy.

In contrast to this, the second quotation by Mezzadra questions the need itself of posing the politics of citizenship in terms of its relationship with the modern sovereignty territorial state. Instead of taking this relationship as a natural starting point for questions about the politics of citizenship, it suggests that it is this relationship in itself that needs to be explored in terms of how it facilitates a particular understanding of politics as a relationship among modern autonomous subjects and/or groups of modern autonomous subjects, in the first place. Quoting Chatterjee, the author implies that this relationship is problematic because it assumes homogenous as opposed to (and thus ignoring the concept of) heterogeneous space. Mezzadra thus renders problematic the notion that the (problematized) state and (deconstructed) subjectivity can be taken as analytical categories in their own right. Instead of merely presuming that the relation between citizenship and state sovereignty can be used to 'explain' and 'rethink' understandings about the nature of subjectivity and agency, his focus shifts to how citizenship and understandings of the nature of subjectivity and agency derive their meaning from claims to state sovereignty (a will to empower). ${ }^{7}$

Unlike the first approach, this line of inquiry emphasizes the need to reflect on how our understanding of political possibility (social, cultural and economic) is limited by our need to think about political life as either within or between modern states. ${ }^{8}$ It focuses on how our imagination is limited by our need to conceptualize the only possible ground for the 'politics' of citizenship as that which is defined in terms of the relationship between autonomous individuals (subjectivity) and the state (sovereignty). It is not merely the location (i.e. the rightful parameters) of political space (for example, whether these should be trans or intra statist) which is being 
questioned here. This is because it is argued that doing so continues to assume a concept of space as homogenous (limitless) insofar as we continue to think of 'being' in space in different ways and to different degrees, rather than of different conceptions of 'space'. ${ }^{9}$ Instead, what is explored is the idea that political space itself needs to be reconceptualized. This is in terms of how it is playing out in often unexpected ways at a multiplicity of sites and the manner in which this challenges the notion itself of instantaneous static space (us/them framework) as the only possible type of political space. ${ }^{10}$ The result is to ask, as Mezzadra does, how this reconceptualization of political space challenges the existing dominant understanding of political life as within or between states as the only way of being when it comes to the question of citizenship and the relationship between citizenship and migration. It is to ask how migration challenges not only the location and authenticity of territorial borders but also "the borders of our imagination". 11

I would like to suggest that the distinction which Richard Ashley and Rob Walker once drew between two possible critical responses to crisis and the question of sovereignty, is useful in order to consider what is at stake in how 'citizens' is conceived of differently in the two strands of thought discussed here. ${ }^{12}$

\section{First Response}

On the one hand Walker and Ashley point to a response which is based on imagining the world in terms of spatially opposed positions of inside and outside and temporal continuity which is then interrupted by a unique moment of discontinuity "that opens up when...continuous time, homogeneous place, and coherent and well-bounded

textual inheritance breaks up or gives away". ${ }^{13}$ This line of reasoning posits the boundaries demarcating 'us' from 'them' in the twenty-first century as sharply 
brought into focus and now highly contested, but ultimately retains the basic notion of the ontological foundation of this dichotomy. That is to say, that despite the concepts of us and them now constantly undergoing deconstruction, identity (inside) continues here to be conceptualized as ontologically against difference (outside) as two separate, albeit interlinked, analytical categories which remain "constitutive of our modern understanding of political space". ${ }^{14}$ Because the subject continues here to be conceptualized as unitary (by theorizing similarity in difference via autonomous subjectivities) 'difference' is defined in terms (always) of Other as one who can be 'included'. This means that political arrangements of sovereignty (the symbolic or social order) are seen in the last instance as separate from the processes of inscription of (grounded) subjectivity. ${ }^{15}$ Sovereignty is seen as that which is required for reality to have meaning and thus political possibility, as opposed to that which merely facilitates a particular type of meaningful reality in terms of what has come to be understood as political possibility.

As Walker discusses in Inside/Outside, what can be identified here is the assumption that the image of the sovereign state as "fixed within precise ontological coordinates" can be applied universally. ${ }^{16}$ Pierre Maxime Schuhl once identified this as the 'the theme of Gulliver'. ${ }^{17}$ To assume this when it comes to the question of citizenship, as Walker discusses further in 'Citizenship after the Modern Subject' is, however, specifically to ignore the question of the historically constituted nature of subjectivity. It is to choose to ignore the decision which is taken in assuming that the limits of the modern state have always been analogous to the limits of subjectivity. Walker focuses here on the manner in which a particular conception of space which is associated with the principle of state sovereignty can be understood to have emerged as a particular way of ordering understandings about subjectivity as well as those 
about political society. ${ }^{18}$ For Walker, focusing on the question of the politics of citizenship primarily vis-à-vis its relationship with the modern territorial state (claims to statehood) ignores how the question of what it is to 'be' citizens came to be defined vis-à-vis its relationship with the state in terms of a very specific concept of space (us/them dualism) and time (progressive, continuous and linear - understood as "a historical process by which peoples develop shared characteristics" ${ }^{\prime 19}$ ) which is based on the understanding of a decisive demarcation in the first place between inside and outside, between self and other, between presence and absence. ${ }^{20}$

\section{Second Response}

The alternative response to crisis and the question of sovereignty that Ashley and Walker envisage is one which is based on specifically questioning what current imaginations of borders and territories tell us about what political community and identity can(not) be. This is a line of inquiry which explores how modern understanding of borders in terms of infinite, invariable and homogenous space which exist in continuous, progressive time - concentrated in claims to statehood and the idea of the (in)complete Cartesian subject - are not the only way of imagining political possibility. It is one which argues rather that this certain dominant understanding merely became dominant "because it was possible for a time...actively to marginalize, forget and defer encounters with paradoxes, contesting themes, and resistant interpretations that...transgress all imaginable boundaries, and that render radically unstable all renditions of unequivocal voice."21

Unlike in the former response, here it is the idea itself of how we draw boundaries (the presumed convergence between boundaries and territorial space, and boundaries and subjectivity) and therefore our understanding of the nature of the limits of modern political life as within and between modern states, that is 
problematized. ${ }^{22}$ It is no longer possible here to simply question where the margins of modern political life should be drawn - as more or less inclusively between the state and citizenship, as more or less inclusively between identity (inside) and difference (outside). Rather it becomes necessary to reconceptualize the manner in which we have been told that we must "think about the delineation of political possibility in both time and space" ${ }^{, 3}$ within or between states and therefore in terms specifically of progressive time (historical narratives) and "inviolable and sharply delimited spaces." ${ }^{24}$ For Walker, we need to explore this by reflecting on the manner in which our current understanding of time and space continue to be intimately related to ideas about state sovereignty which were crystallized in Early-modern Europe and which are associated specifically with classic Newtonian physics and Euclidean geometry. We need to look at how classical physics, which assumes the independence of space from the matter which it contains and "the linearity of historical, narrativised time, time which has beginnings and ends" 25 , is constitutive of our understanding of modern 'political' subjectivity. ${ }^{26}$ Walker's argument in relation to citizenship is that the question itself of how the politics of citizenship is being challenged cannot be divorced from this modern account of individual subjectivity that forms, to begin with, the basis for our understanding of 'political' (im)possibility in contemporary circumstances.

\section{A Lens: The 2004 Irish Citizenship Referendum}

In the discussion that follows I want to explore in more detail this division among responses to the question of how migration demands a radical retheorization of citizenship. To do so I propose to take the example of the 2004 Irish Citizenship Referendum and compare three critical forms of analysis of this event. Prior to 2004, 
everyone born on Irish soil was entitled to become an Irish citizen. This entitlement was enshrined in Article 2 of Bunreacht na hÉireann (Irish Constitution). In 2004, however, $79.2 \%$ of the electorate agreed to remove via referendum the existing constitutional entitlement to birthright citizenship of children who were born to nonnational parents. ${ }^{27}$ The 2004 Irish Citizenship Referendum is an event which has been attributed to an increase in immigration over the previous decade but with which there is widespread disagreement as to how the subsequent response of a change in constitutional entitlement to birthright citizenship should be interpreted. This disagreement echoes debates elsewhere insofar as it has been articulated as a clash between, on one hand, universal theories of citizenship which maintain that increased regulation in this area is discriminatory and, on the other hand, more particular theories of citizenship which defend the need for regulations and controls in the area of citizenship. Most significantly, this change in Irish birthright citizenship legislation follows the introduction of restrictions to automatic birthright citizenship legislation introduced in India (1987), Australia (1986), New Zealand (2006) and South Africa (1995). ${ }^{28}$ Therefore, while in one respect debates and discussions surrounding the Irish Citizenship Referendum in 2004 have, in focusing on how changes in citizenship legislation have disproportionately affected certain communities, invoked existing debates in Europe which specifically explore the question of whether increased regulations in this area could better be described as 'racism' or 'commonsense'. ${ }^{29}$ In other respects, the focus in the Republic of Ireland, which was specifically on the children of migrants (often undocumented) as those who were deemed to be lacking sufficient 'connection' to the country ${ }^{30}$, can be seen to resonate much further afield. This includes in the Dominican Republic which has similarly seen increased restrictions on the entitlement to birthright citizenship for the children of certain 
residents via discussions about the appropriate association (deemed to be best described as 'in transit') of these residents to the Dominican Republic. ${ }^{31}$

It is on the premise that approaches towards the reconceptualization of citizenship in the Republic of Ireland in 2004 resonate in this manner with debates elsewhere, that existing analysis of the 2004 Irish Citizenship Referendum will be considered here. Three different forms of critical analysis of the 2004 Irish Citizenship Referendum will be explored. In the first and second instances a gendered and cosmopolitan approach will be discussed respectively. A third critical analysis of the 2004 Irish Citizenship Referendum will then be considered. This is one which explores how citizenship is mediated via sociospatial processes. Existing analysis of changes in citizenship legislation tend to concentrate on the question of 'who' is further included or excluded from understandings of citizenship as a result of these changes and/or 'how'. ${ }^{32}$ From this perspective, gendered, cosmopolitanism, racial, sociospatial, economic and nationalist theories etc. of citizenship are all perceived to be contending (albeit not necessarily contradictory) theories, insofar as they each provide different solutions as to how the tension between sovereignty and subjectivity could be negotiated in this context. Asking how the three theories of the 2004 Irish Citizenship Referendum referred to above can be mapped onto the two different types of responses which Ashley and Walker identify to crisis and the question of sovereignty is to seek, alternatively, to highlight similarities among many of these supposedly contending reconceptualizations of citizenship, however. It is to seek to differentiate instead between conceptualizations which challenge the understanding that the relationship between sovereignty and subjectivity must form the basis of the question of the 'politics' of citizenship, and those which do not. 
It will be argued that the first two forms of critical analysis (the gendered and cosmopolitan approaches) can be equated with the first response which Ashley and Walker identified. This is on the basis of their insistence on conceptualizing challenges from migration to understandings of solidarity in terms primarily of how these have merely interrupted existing spatial and temporal boundaries and therefore can continue to be negotiated via appeals to sovereignty and thus in terms of absolute space and linear, progressive conceptions of time. As an alternative to this, it will be pointed out that the third analysis, unlike the previous two, considers how migration specifically problematizes the relationship itself between identity and the idea of absolute space which is inherent in claims to state sovereignty. It will be argued that this third approach therefore corresponds to the second response which Walker and Ashley identified insofar as it specifically aims to deconstruct dominant understandings of the necessary relationship between identity and the location of that identity as that which must correspond to a coherent subject in the last instance in order to speak about a 'politics' of citizenship.

\section{RETHEORIZING CITIZENSHIP: A POST-RACIAL MODEL OF CITIZENSHIP}

The referendum campaign was conducted using gendered, racialized discourses of blame against migrant women who were allegedly having babies solely to gain Irish citizenship for their children... - Lentin and Luibhéid ${ }^{33}$

In 2004 the Twenty-Seventh Amendment to the Constitution was passed (by a four to one majority) in the Republic of Ireland. This saw the existing automatic constitutional entitlement to birthright citizenship for people born to 'non-national' parents removed and replaced with a residency requirement. ${ }^{34}$ The existing automatic 
constitutional entitlement to birthright citizenship, inserted in 1998 as Article 2, declared that it was both the entitlement and birthright of "every person born in the island of Ireland...to be part of the Irish Nation and to be citizens of Ireland". 35 However, in 2004 the Irish Government argued that automatic entitlement to Irish citizenship had begun to pose a threat to Irish sovereignty insofar as it was restricting the state's ability to regulate entry into and residence within the state and providing a 'backdoor' into Europe. As proof of this threat, the Government pointed to the increase in the rate of births to non-national women in recent years. They argued that the automatic entitlement to birthright citizenship was creating an incentive for people from abroad to travel to Ireland to give birth and secure Irish citizenship for their children which in turn was producing a number of Irish citizen children who lacked sufficient 'connection' to Ireland. A "disproportionate number" of non-national mothers giving birth in Irish hospitals was at the time attributed specifically to the birth rate among asylum seekers (which at $58 \%$ was seen as "an extraordinarily high rate in comparison to normal population standards") and to 'anecdotal' evidence of women flying into the country on tourist visas to give birth, collect a passport for their children and return home. ${ }^{36}$ In 2004 the electorate was therefore asked, and agreed by a $79.2 \%$ majority, to amend the existing automatic constitutional entitlement to birthright citizenship by inserting the following additional clause into the Constitution:

Article 9.2.1 Notwithstanding any other provision of this Constitution, a person born in the island of Ireland, which includes its islands and seas, who does not have, at the time of his or her birth, at least one parent who is an Irish citizen or entitled to be an Irish citizen is not entitled to Irish citizenship or nationality, unless otherwise provided for by law 
One of the main oppositions to the Government's assessment of the situation in 2004 is a gendered racial critique of the perceived 'commonsense' threat which certain people were understood to pose to the integrity of Irish and European citizenship legislation in the early twenty-first century. This gendered analysis specifically seeks, on the contrary, to explore how the arrival of certain mothers and their 'Irish-born children ${ }^{37}$ as immigrants into a country which perceived itself to be largely mono-cultural worked "to subvert traditional understandings of citizenship and 'the nation', dragging Irish modernity kicking and screaming into the chaos of the postmodern" ${ }^{38}$ It thus sets out to radically retheorize the notion itself of 'Irish' citizenship by examining how Ireland's experience in the twenty-first century of migration undermines traditional understandings of citizenship which are defined according to dominant ideals and practices of solidarity located (solely) in the national community. In doing so, it argues that so-called common-sense responses are in fact racialized attempts to control "not only in-migration but also the self-definition of existing collectivities within". ${ }^{9}$ The way in which this must be subverted, it maintains, is by beginning to (re)imagine the possibility of political community outside and beyond the clearly delineated boundaries of the nation state so as to facilitate "an interrogation of how the Irish nation can become other than white (Christian and settled)". ${ }^{40}$ It argues that only in this manner can we begin to imagine understandings of belonging which are 'inclusive' as they will no longer be dictated by the exclusionary, racist boundaries of the Irish statist project. ${ }^{41}$

Focusing on the connection which was made between reproductive and residency rights in two key court cases involving the state and migrant families between 1990 and 2003, this critique highlights the centrality of the role of migrant women and their Irish citizen children in the debate over citizenship rights in 2004. In 
1990 in the Fajujonu v. Minister for Justice case, the Irish Supreme Court ruled that two undocumented migrant parents (a Moroccan national and a Nigerian national) had the right to remain in Ireland to provide 'company, care and parentage' to their Irish citizen child within the state on the basis of a child's entitlement to company and protection of their family as set out in Articles 41 and 42 of Bunreacht na hÉireann. As a result of this ruling it is estimated that approximately 10,000 people subsequently applied to remain in Ireland on the basis of what became known as "the Irish born child scheme'. ${ }^{42}$ In 2003 the Supreme Court then ruled, however, that a non-national parents' right to remain in Ireland to bring up their Irish citizen child could be weighed against the additional importance of the integrity of the asylum process and the state's right to control entry into and residence within the state. ${ }^{43}$ The Irish Government subsequently suspended any dealings with the practice of appeals for residency in Ireland on the basis of an Irish born child as a separate process to other migration/asylum claims. ${ }^{44}$

This enshrinement of the (il)legitimacy of certain types of m(others) whose own non-national status was taken to delegitimize the right of their offspring to live in Ireland as other Irish citizens do with the care and company of their parents, has been heralded by this gendered analysis as a precursor to the arguments which were subsequently made by the Irish Government in 2004 regarding the 'need' to remove automatic entitlement to citizenship at birth so as to put an end to what it categorized as further 'abuses' of the system. Arguing that women were presenting at hospitals around Ireland having undertaken journeys from abroad in late pregnancy, the Irish Government put forward prior to the referendum on citizenship in 2004 that 
[t]he inescapable conclusion is that non-national parents, whether based in Ireland or not, quite reasonably perceive an advantage by giving birth in Ireland to a child who thereby becomes an Irish, and thus an EU citizen ${ }^{45}$

Yet it is precisely this 'fact' of a direct correlation between the constitutional entitlement to birthright citizenship and of the actions of migrant parents, in particular migrant mothers, which is disputed. In the first instance, it has been pointed out that the practice of late arrival in the three main maternity hospitals in Dublin is far from an uncommon occurrence, with Irish citizens as well as so-called non-nationals presenting late in this manner. ${ }^{46}$ This has led to questions as to why it was therefore specifically migrant women who had been singled out in this regard by being “signified as 'other' and stereotyped as sexually active child-makers, deliberately subverting Irish norms of citizenship and nationality". ${ }^{47}$ Lentin, Garner and Luibhéid all consider in this respect how racialized female migrants have come to embody the boundaries of 'Irish' society by virtue of their role as reproducers of future generations of (non)Irish offspring and suggest that the 2004 Citizenship Referendum represents the culmination of attempts by the Irish state to privilege increasingly narrow concepts of 'Irishness'.

Migrant mothers who are recognized as being 'outside' the imagined Irish community due to their lack of formal Irish citizenship have been focused on here as those who can transgress the narrow boundaries of Irish citizenship through their presence within the Irish state. Attempts to theorize a postmodern conception of citizenship has seen subjectivity therefore theorized in terms of an ability to resist or not, against the boundaries of (because 'being' is always already defined as inclusionable or exclusionable in) the state. Where subjectivity is conceptualized in terms of the ability to resist the state, however, it remains tied to the concepts of sovereignty and autonomy. This reinforces a particular assumption about what and 
where political life can be. It is to locate it either in the exercise of sovereignty under state law or, in the interruption of the exercise of sovereignty under state law. ${ }^{49}$ The emphasis here, in other words, is ultimately on a clear demarcation between identity (inside) and difference (outside) insofar as the focus is on how this demarcation is specifically challenged by the presence of the migrant mother. Albeit reconceptualized in less antagonistic terms, what it is to be 'citizen' in relation to the question of migration remains based in this analysis therefore upon an absolute spatial and unified linear temporal distinction between here and there, this community and that.

Having established how the notion of 'citizen' is reconceptualized via a postracial model in the existing gendered analysis of the 2004 Irish Citizenship Referendum the next section considers the cosmopolitan analysis which has been offered as an alternative to this.

\section{RETHEORIZING CITIZENSHIP: A POST-NATIONAL MODEL OF CITIZENSHIP}

The effect of the 2004 Referendum on Citizenship was to narrow the empirical definition of what it meant to be Irish, inventing the conundrum of the Irish-born nonIrish child as a perverse twenty-first century civics lesson...The challenge is to come up with ways of binding the Irish to their diverse nation-state as well as integrating the new guests of the nation. - Bryan Fanning ${ }^{50}$

A second attempt to reconsider the perceived 'commonsense' threat to Irish citizenship articulated by the Irish Government in 2004 is based on a cosmopolitan analysis of this event. This analysis has been articulated as a direct alternative to the 
overriding emphasis on the notion of a racial or racist state which formed the basis of the aforementioned gendered critique of the 2004 Irish Citizenship Referendum. ${ }^{51}$ Although not contradicting the gendered racialized critique outright, this analysis has sought to emphasize that support for commonsense restrictions on citizenship in the republic Ireland in the twenty-first century can not only be explained in terms of racism and/or exclusivist understandings of nation building. It argues that the overwhelming endorsement for the change in the basis of birthright citizenship needs rather to be explored in terms of the manner in which the populist distinction itself between 'nationals' and 'non-nationals' which crystallized in the 2004 Citizenship Referendum was institutionalized by way of a combination of distributional anxiety shaped by past economic fatalism (economic Othering) as well as a racialized concept of citizenship "anchored in past exclusionary monocultural nation-building ideologues of Irishness" (cultural Othering). ${ }^{52}$ Similar to the gendered analysis, the outcome of the 2004 Citizenship Referendum is attributed here to the rapid social change brought about by migration into the country over the previous decade. Unlike the gendered analysis, however, which emphasizes the need to conceptualize a post-racial model of citizenship, what is proposed here to deal with the challenge which immigration poses to dominant ideals and practices of solidarity in the Republic of Ireland (the dominant imagined community) is a post-national model of citizenship which is based on the notion of "binding trans-national human rights". 53

In 'Nationals/Non-nationals: Immigration, Citizenship and Politics in the Republic of Ireland', Fanning and Mutwarasibo set out in this regard to specifically problematize the notion of there being a straightforward link between nationalism and racism in the Republic of Ireland. They do so by focusing on how a distinction can be drawn in the debates surrounding the 2004 Citizenship Referendum between those 
discussions which simply reinforced the assumption of a difference between nationals and non-nationals, and those which actually employed racialized hostility towards certain parents and their Irish citizen children in doing so. The underlying message here is that understandings about citizenship in the Republic of Ireland are intimately connected to nation-building and the nationalist project more generally and need to be understood as something which is bound up therefore with processes of inclusion and exclusion and not simply with processes of exclusion. Although, therefore, not shying away from looking at how, over the previous century an understanding of Irishness associated with ethnic homogeneity did become central to the process of building an 'Irish' national project and exploring how this was mobilized in 2004 to encourage narrow racialized conceptions of Irish solidarity. What is primarily emphasized in this approach is the potential which supposedly still exists for conceptualizing complementary cosmopolitan conceptions of solidarity in the Republic of Ireland in the twenty-first century which this time infuse the nation-state model with more inclusive ideals. As Fanning explains:

A cosmopolitan citizenship ideal is essentially a post-national one that allows for inclusion within the nation-state in the absence of [formal] naturalization. Advocates of cosmopolitanism endeavor to shift the focus of debate away from the sort of adversarial 'zero sum' game of playing 'nationals' against 'non-nationals'. They emphasise and obligation to be hospitable towards immigrants rooted in a Kantian conception of reason. ${ }^{54}$

Fanning is insistent here that this cosmopolitan model of citizenship is based on "a realistic conception of the limits of solidarity" which acknowledges that in a world without the right to have rights, it is nation-states which (will) remain centre stage. ${ }^{55}$ His argument is that it is states and states alone "which integrate immigrants or otherwise manage them as part of an ongoing process of economic, social, political 
and organizational nation-building". ${ }^{56}$ Therefore, and echoing the point made by Castles and Davidson in the quote which opened this paper, he maintains that any solution to the challenges which immigration poses to dominant ideals and practices of solidarity needs to focus on how we can (continue to) resolve understandings about what and where political community can be, in terms of claims to state sovereignty.

The idea of 'inclusion' presented here is always as inclusion of a coherent subject in the last instance - normally 'immigrants' and or 'ethnic minorities'. This is done by conceiving of subjectivity in a similar manner to that of how political community is conceived: as that which fluid margins, but also edges which can be filled. The conception of space presented here is therefore absolute, infinite but most importantly, homogenous. Similarly, time is conceived here singularly as progressive: one becomes a citizen having not previously been one. The shift is from 'old' forms of citizenship and groups of old citizens to 'new' forms of citizenship and groups of new citizens. The possibility itself for the renegotiation of the relationship between citizenship and immigration is thus reaffirmed here anew in terms of absolute and independent space as well as linear, continuous and progressive time. This is to point out that despite attempts to deconstruct 'Irishness' and its association with the idea of an originary identity, the alternative emphasis here on 'guest' versus 'host' results in a certain reinforcing of the idea itself of how we are supposed to (continue to) think about the relationship between immigration and what it means to be(come) a citizen. As the increasing use of the term 'new Irish' attests to, this is the idea that we must think this relationship via specific spatial and temporal notions of difference and identity where difference is understood to intersect with, but remains in the last instance, spatially external to, and following temporally in the wake of, identity. ${ }^{57}$ 


\section{RETHEORIZING CITIZENSHIP: A SOCIOSPATIAL MODEL OF CITIZENSHIP}

Before turning to the third attempt to reconsider the perceived commonsense threat to Irish citizenship in 2004 , it is necessary to recap briefly on the manner in which the politics of citizenship has been conceived in the other two critical responses discussed. So far it has been argued that both approaches continue to pose the question of the politics of citizenship in similar terms. This is in terms of how (deconstructed) individuals are positioned in relation to the (sub, supra or super) state as included or excluded. This, it has been argued, reproduces an understanding of subjectivity which remains associated with a very particular conception of time and space. This is an understanding of subjectivity as based on a continuing essence in (as opposed to 'of') time and space which is split between a particular identity (citizen) and a universal identity ('Wo/Man'). Although these accounts have produced an alternative history of Ireland as a multi-ethnic society which is made up of various identities - old Irish/new Irish, host/guest, minority/majority - rather than a history in which there is just one authentic identity (Celtic), the argument made here is that this has been done without ultimately undermining the opposition itself (conceptualized in terms of homogenous, invariable space and linear, progressive time) between notions of 'us' and 'them', this community and that community, between 'here' and 'there'.

I now intend to explore a socio-spatial analysis of the 2004 Irish citizenship Referendum and discuss how this specifically challenges said understandings of the relationship between citizenship and immigration which posit subjectivity in terms of absolute space. It will be suggested in the final section that this challenge can be understood in terms of how it provides the conceptual space to consider subjectivity rather as 'trace'; as contingent spaces which make impossible the notion of a coherent 'I' which can be included or excluded in the first place. As will be discussed, this is 
insofar as the socio-spatial analysis is a response which undermines the notion of a coherent 'self' which corresponds to a solid body and is always containable "within a unified narrative or bounded political community". ${ }^{58}$ It will be argued that this type of response to the challenges which migration poses to dominant conceptions of belonging, in contrast to the former two, problematizes the notion itself that an us/them dualism must always form the basis of an understanding of the politics of citizenship. It does so by replacing the assumption of the self as a territorial sovereign being which needs to be bonded with another, with an understanding of the various ways in which citizenship can be thought of as a condition of rupture within the notion of the (coherent) self and within (coherent) 'selves' across time and space.

\section{A Sociospatial Analysis}

Although not as dominant as the aforementioned gendered and cosmopolitan approaches, the beginnings of a third type of critical analysis of the 2004 Irish Citizenship Referendum can be identified among the continued inquiries into the question of Irish citizenship and its future possibilities. This response is fragmented and does not attempt to 'resolve' the issue of Irish citizenship in favour of an alternative (such as that of a more inclusive) conception of citizenship. Rather, expressly denying the inevitability of any type of universal progressive politics, it seeks to highlight how citizenship has been fixed through the articulation of a specific relationship between identity (people) and place (territory) - in terms of an inclusion/exclusion framework - and considers how this might be challenged. It asks us to (re)think being citizens: in terms of geographies, rather than the geography, of citizenship. $^{59}$ 
In 'Critical Geographies of Citizenship' White and Gilmartin explore similar concerns to that of the aforementioned cosmopolitan and gendered approaches. This is mainly those regarding the relationship which has been established between reproductive and mobility rights. However, in doing so these authors do not focus on the question of 'who' is included and/or excluded from the Irish statist project and 'how' but on "[t]he existence of a reservoir of contradictory claims, anxieties and ambiguities surrounding the politics of abortion rights, mobility rights and the pregnant body in Ireland". ${ }^{60}$ Pointing out the importance of the notion of mobility underlying the concept of migration here, they emphasize how the question of citizenship in relation to these issues plays out in a variety of ways, many of which ultimately challenge the idea itself that the notions of 'people' (individual) and 'place' (sovereign territory) can be theorized as coherent analytical categories in their own right. These concepts, which the other approaches take as starting points when asking who is excluded from Irish citizenship and how, are instead posited by these authors as contingent sites in themselves, around which legal and political arguments and claims about subjectivity are precariously organized. ${ }^{61}$

This is done by exploring the manner in which the battle for what it is to be a 'citizen' in Ireland in relation to the issue of birthright can be shown to have always lacked the type of foundation in a unified self necessary to pose the question of 'who' in the first place. Pointing out that no less than five constitutional referenda proposals were debated over a twenty year period regarding the concept of 'the right to life of the unborn' (the phrase which enshrined abortion as illegal in the Irish Constitution in 1983), White and Gilmartin highlight the manner in which these referendums belie any coherency or stability underlying conceptions of child or woman as 'citizen' in the context of debates about pregnancy in the Republic of Ireland. Rather, they argue 
that these referendums reflect the manner in which the space of 'woman' and 'child' have more generally become in themselves "sites of conflict over the broader meanings of family, state and the law". ${ }^{2}$ In this manner Gilmartin and White's work indicates that the relationship which was established between reproductive and residency rights in an Irish context - via the Fajujonu case in 1990 and the Lobe \& Osayande case in 2003 - and the question of how this led to the focus on the (il)legitimate presence of non-national women in the capital's main maternity hospitals in 2004, can be explored in terms of geographies of belonging and exclusion which traverse, and therefore destabilize (as opposed to necessarily always reinforcing) legal discourses regarding reproductive rights. They destabilize them insofar as they reveal the ambiguous nature of the coherent 'subject' which supposedly sits at the centre of such claims. For example, White and Gilmartin focus on the manner in which the judges in two high profile cases in the Republic of Ireland involving a 14 year old (the $\mathrm{X}$ case) and a thirteen year old (the $\mathrm{C}$ case) who got pregnant as a result of being raped and who subsequently sought to go abroad to terminate their pregnancies, described them variously as 'young girl', 'girl', 'mother' and 'girl/mother' ${ }^{63}$ In doing so White and Gilmartin draw attention to how the idea of a sovereign autonomous subject makes little sense in relation to these cases. Their work points out that it is not possible here to think 'citizen' in time-space coordinates as normally associated with the understanding of a progression from the space of childhood on one hand to that of motherhood on the other. Rather, their work emphasizes that the boundaries themselves are collapsed here between the already born and yet unborn 'child' and between 'child' as foetus and 'mother' as woman. The result is 'citizen' of multiple time-space coordinates; each resulting from the 
different configurations of how the relationship between state, family and unborn child is articulated. ${ }^{64}$

Here we see a shift in focus from casting citizenship and the meaning of what it is to be 'citizen' in terms of a metaphysics of homogenous absolute space according to which an us/them dualism make sense, to that of casting it in terms of a metaphysics of heterogeneous contingent spaces in which this dualism itself is collapsed as identity and difference are no longer defined in terms of an ability to separate inside from outside. Suddenly, this notion of needing to bring migrant and Irish together within a more inclusive conception of citizenship is no longer the only way of thinking about the relationship between migration and what it means to be a citizen. Instead, because the notion of 'citizen' is reconceptualized as lacking in itself a unified basis, the relationship between identity (citizen) and difference (migrant) becomes more ambiguous. It becomes less recognizable in terms of an ability to draw lines in the final instance between those outside and those inside the dominant imagined community, between 'migrant' and 'non-migrant', between 'host' and 'newcomer', between the past (old Irish) and the present (new Irish). These spaces are no longer so easily idealized as solid bodies analogous to the image of the sovereign territorial state which exists in linear time moving from the past to the present and back again, but rather as often retrospectively produced, highly ambiguous 'traces'.

The implication is that the relationship between reproductivity and residency needs to be set in terms of an appreciation of the interrelated (and often contradictory) identities-spaces around which political and legal claims have been organized to date, not all of which are sovereign spaces. What is opened up here is a 'supplementary' space of subjectivity and thus of being 'citizen'. This is not, however, a different coordinate in existing time-space understandings which simply 'adds up' to another 
space in time in which the sovereign subject experiences citizenship - as, for example, the concept of 'new Irish' alludes to. Rather this is a supplementary space that suggests that adding 'to' need not 'add up', but may rather disturb the existing calculation. ${ }^{65}$ Here, the notion of 'citizen' envisaged as mother with child or mother/child is never enough. Instead the claim to citizenship is always in excess of either the space or time of 'mother' or 'child'. Citizenship thus becomes that which redraws the frontiers of 'difference' in such a way "that never quite adds up, always

less than one...and double". ${ }^{66}$ Subjectivity is still conceptualized here as comprising identity and difference but difference (outside) is no longer necessarily spatially or temporally distinct from identity (inside). Difference is rather conceptualized as "an otherness...without boundary, without end. An otherness barely touched upon and that already moves away". 67

\section{RETHEORIZING CITIZENSHIP: AS CONTINGENT TRACE RATHER THAN ABSOLUTE SPACE}

As already pointed out, the debates surrounding the 2004 Irish Citizenship Referendum and their subsequent analysis have particular resonance in a global context. What has been shown here is the insistence of both the gendered and the cosmopolitan approaches on the need to respond to the challenges which immigration poses to dominant ideals and practices of solidarity via a rearticulation of existing claims to state sovereignty - a post-racial global gendered conception of city space on one hand, and in terms of some form of transnational humanism, on the other. Here we can see that the question itself of what a new 'politics' of citizenship should be in response to the challenges presented by migration in the twenty-first century, is to some extent constrained in advance. This is because it is predetermined by how the 
notion of political possibility is defined in the first place as 'being' (citizens) within or beyond modern territorial states, bringing with it the need to think in terms of sovereign subjectivity in the last instance. Notwithstanding the difference in emphasis on how the tension between sovereignty and subjectivity should be negotiated, the point is that the overall focus of both approaches remains on the need to 'bring in' certain people who have been left outside of the dominant imagined community and therefore on their assumed ability to be brought in in a coherent fashion. In contrast to this, it has been suggested that the socio-spatial response indicates an alternative way of conceiving of political subjectivity. This is one which does not conform to conceptions of personhood that focus on the individual and thus on a coherent self which is positioned vis-à-vis the state but which opens up an alternative understanding of being 'citizen' via a conception of space (and time) as a series of disruptions and discontinuities.

The point is not that socio-spatial concepts of citizenship are therefore necessarily 'better' than non socio-spatial concepts of citizenship. On the contrary, the political nature of both is stressed here. Rather, what is being underlined is the need to consider the manner in which, unlike in non socio-spatial articulations, the possibility for be(coming) 'citizen' is being conceptualized in socio-spatial concepts of citizenship in often highly unfamiliar and increasingly unrecognizable ways. In order to understand why we might want to explore this it is pointed out here that critical citizenship studies has focused in recent years on the manner in which citizenship is increasingly being experienced in highly irregular ways which often do not make sense according to dominant 'political' horizons. These studies show that the normal straightforward processes through which citizens have been understood to be made and unmade need to be rethought in terms of increasing ambiguity and contradiction. 
In his work Peter Nyers, for example, stresses how progressively experiences of citizenship "do not necessarily involve dramatic denationalizations or formal revocations of citizenship. Instead, we are witnessing arguably more complex cases where citizenship has not been revoked per se, but where it has been rendered inoperable, or irregularized."

Anne McNevin's work presents another important example in this respect. Instead of thinking in terms of the making of 'new' (in contrast to 'old') citizens and the assumptions regarding the realizing of essence in time and space which this assumes, Anne McNevin considers the highly contradictory notion of "undocumented citizens". ${ }^{69}$ This notion is, as McNevin is quick to point out, a contradiction in terms according to dominant territorial defined accounts of political belonging where citizenship has come to signify that which precisely differentiates the newcomers (migrants) from the existing population (citizens). Using three examples (student activism, worker cooperatives and parent mobilizations) McNevin points out, nonetheless, how undocumented migrants, through making political claims on the communities from which they are supposedly excluded, can be seen to renegotiate the terms of political association outside of the norms associated with sovereign citizenship. The notion of 'undocumented citizen' is thus explored here as an alternative form of 'political' belonging which today implicates those with ambiguous or insecure forms of immigrant status. ${ }^{70}$ McNevin points out that in many cases the forms of political subjectivity produced here - for example, involving undocumented students who have grown up in the U.S and therefore do not unambiguously belong elsewhere but nonetheless will graduate from U.S universities without the right to work in the U.S - do not therefore make sense in terms of existing fixed territorial identities whether these are trans, intra or supra statist. They need rather to be 
understood in terms of how "emerging political subjectivities and the sociospatial relations in and through which they emerge are incommensurable with the national territorial-baggage attached to the language of [sovereign] citizenship". ${ }^{71}$ Instead of an understanding of citizenship as an acquired status over time which is associated with particular individuals, McNevin emphasizes here how citizenship is experienced at irregular, often disjunctive moments that undermine the notion of fixed relations to place including jurisdictions, homelands, communities and a coherent 'self'. She stresses that the children of migrants are not people who have been 'left out' of political community but are people who contest the grounds for the basis of the clear distinction between inside and outside, between illegal and legal, between us and them, now and then, and between here and there which dominant conceptions of politics rely upon in the first place. ${ }^{72}$

As Jenny Edkins points out, starting with the question of how we might establish a bond between us - between those inside the state and those outside of it, between migrant and non-migrant, between us and them - ignores the question of how it is that we consider ourselves as separate in the first place. ${ }^{73}$ It ignores precisely the manner in which citizenship and being citizens has become associated with sovereign autonomous understandings of the absolute space and progressive time of subjectivity. The subjectivity of Irish citizen children born to migrant parents in Ireland prior to 2004 and elsewhere around the world (for example in the Dominican Republic) today does not require the building of bonds but rather an exploration of how these children are always already bound in many ways to each other, to Irishness/ Dominican Republicness and non-Irishness/non-Dominican Republicness alike, as well as to all types of (m)others. These are people who are already tied in many ways to the society in which they have grown up in; albeit in ways which are often not so 
easy to fit into traditional notions of inclusion and exclusion which can be associated with a conception of time as a progression between past and present, the national and the international. Instead, what is increasingly evident is that even being born a 'citizen' does not preclude it being "rendered inoperable, or irregularized" in other respects. ${ }^{74}$ An alternative concept of time is presented here to that of progressive time insofar as it becomes possible to imagine how exclusions can continue to be experienced despite someone having 'acquired' citizenship status - for example, to imagine how the citizens born to migrant parents will not always necessarily be recognized as 'citizens', nor their children in future generations to come. ${ }^{75}$ Yet, both the gendered and the cosmopolitan approaches offered fail to imagine how Irish citizen children might be citizens in this regard because they continue to think within the understanding of a particular type of politics: this is "the politics of drawing lines" and anticipating mobilities between here and there, between identity and difference, between us and them. ${ }^{76}$

In contrast, the sociospatial approach discussed presents the conceptual space to imagine how Irish citizen children born to migrant parents, as those who are neither inside or outside the state but who occupy both positions at once, can be conceptualized as 'citizens'. This is because unlike the gendered and cosmopolitan analysis of the 2004 Irish Citizenship Referendum where the notion of an us/them dualism is merely neutralized, this dualism is collapsed in itself. It is no longer taken for granted that subjectivity must be defined in terms of (a universal humanity that transcends or compliments) the state, and therefore as coherent and sovereign in time and place. Instead through an exploration of how the question itself of what constitutes 'the subject' is contested in debates surrounding the issue of childbirth, it becomes possible to think 'citizens' in terms outside this type of (modern) subject. 
The result is that citizenship experienced in terms of spatial and temporal inconsistencies (traces), of presence and absence is conceptualized once again as 'political' subjectivity. As opposed to needing to consider how the experience of citizen children born to migrant parents can be 'made sense' of in relation to existing imaginaries of political community which are based on sovereign notions of inclusion and exclusion, this allows us to consider such ambiguous subjectivities in their own right. The notion of 'trace' seeks in this manner to provide new conceptual vocabulary for the alternative notions of political belonging which are being imagined by critical citizenship studies. It seeks to respond to those who are conceiving of newness in a manner "that is not part of the continuum of past and present...[but] renews the past, refiguring it as a contingent 'in-between' space of subjectivity, that innovates and interrupts the performance of the present". ${ }^{77}$

\section{CONCLUSION}

If we acknowledge disjoint forms of presence, a politics of citizenship will require a continuous renegotiation of the aggregation of difference, an appreciation of an uneasy coexistence of subjects who live in overlapping but different [spatio]-temporal traces. - Michael J. Shapiro ${ }^{78}$

This paper has sought to explore a divergence in citizenship studies literature in relation to the approach itself to the question of how a new 'politics' of citizenship should be theorized in response to the issue of migration - as that which must be conceptualized vis-à-vis its relationship with the sub/ supra or transnational state, or not. It has suggested that what is at stake in this divergence is the difference between a continued understanding of political subjectivity in terms of an us/them, here/there, 
past/present dualism in the final instance, or an attempt to specifically undermine this. The former has been discussed in terms of how it (re)produces a conception of what it means to become a 'citizen' in terms of the absolute and coherent space of self as that which can resist the state and be(come) (re)included in the statist project; the latter has been shown to introduce a conception of contingency which makes impossible the notion of a coherent self which sits at the centre of claims to the right itself to resist and/or be included in the statist project. As White and Gilmartin point out, despite the "aura of fixity and permanence, our discussions and arguments reveal how these [claims] are based [instead] upon mutable and changing constructions and conceptualizations of the relationship between identity and space."79

Instead of different spaces of citizenship such as old and new, inclusive and exclusive - which is to conceive of being 'citizen' (matter) as that which exists in time and space which act as 'containers' or the 'backdrop' for social life - the concept of citizenship as trace' has been introduced in this paper to attempt to capture the alternative conception of political subjectivity articulated here. What is challenged in this concept of 'trace' is the image of political space as having to be understood as something to be achieved in unified time and extended in space and thus always in terms of the oscillation between continuing presence and imminent absence. ${ }^{80}$ Through this notion we are rather left to imagine 'citizens' as a form of subjectivity which can manifest as a cluster of time-space coordinates which are constantly changing within and across what is normally conceptualized as the absolute space and horizontal time of sovereign political community.

It is not argued here that a better ontology necessarily gives us a better politics. ${ }^{81}$ What is being argued, however, is that a better ontology gives us the ability to see the different ways in which the politics of citizenship can, and more 
importantly, is being articulated. The notion of trace presented here is best understood as an attempt to consider how so many people are already responding to the ongoing challenges to dominant understanding of the relationship between space, time and matter associated with classical physics. As Edkins points out, it is not that we need to catch up with ways of thinking about time and space in light of contemporary scientific analysis. ${ }^{82 \dagger}$ Rather we need to understand how classical conceptions of time and space are integral to structures themselves of sovereign power. We therefore need to ask ourselves how we can continue to tease out the conceptual difficulties in understanding these challenges given the continuing dominance of this power structure.

\section{Notes}

An earlier version of this paper was presented at the Aberystwyth Citizenship Studies Research Group and the International Studies Association Annual Conference 2010. The author would like to thank Ronaldo Munck, Kenneth McDonagh, Jenny Edkins and Peter Nyers for critical engagement with the main arguments. The author gratefully acknowledges the financial assistance of the Irish Research Council of Humanities and Social Studies.

\footnotetext{
${ }^{1}$ Stephen Castles and Alastair Davidson Citizenship and Migration: Globalization and the Politics of Belonging, (London: Macmillan Press, 2000), p.viii

${ }^{2}$ Sandro Mezzadra 'Citizen and Subject: A Postcolonial Constitution for the European Union?', (2005) p.5 [online] Available from: http://www.gold.ac.uk/media/mezzadra_citizen_subject.pdf [Accessed 13 April 2010]

${ }^{3}$ R.B.J. Walker 'Citizenship after the Modern Subject' In: K. Hutchings and R. Dannreuther, (Eds.) Cosmopolitan Citizenship (London: MacMillan Press Ltd, 1999), p.179

${ }^{4}$ Angharad Closs Stephens “'Citizenship without community: Time, design and the city', Citizenship Studies, Vol.14, No.1, (2010) p.41 (emphasis added)
} 
5 Jürgen Habermas Between Facts and Norms: Contributions to a Discourse Theory of Law and Democracy (Cambridge: Polity Press, 1996), p.515

${ }^{6}$ Walker 'Citizenship after', note 3, p.179

7 Mezzadra 'Citizen and Subject', note 2; See also, Barbara Cruikshank The Will to Empower: Democratic Citizens and Other Subjects (Ithaca and London: Cornell University Press, 1999)

${ }^{8}$ R.B.J. Walker 'Sovereignties, Exceptions, Worlds' In: J. Edkins, V. Pin-Fat and M. Shapiro, Eds. Sovereign Lives: Power in Global Politics (London: Routledge, 2004), pp.239-249; Peter Nyers 'Emergency or Emerging Identities? Refugees and Transformations in World Order', Millennium Journal of International Studies, Vol.28, No.1, (1999) pp.1-26

${ }^{9}$ R.B.J. Walker 'The Territorial State and The Theme of Gulliver' In: R.B.J Walker. Inside/Outside: International Relations as Political Theory (Cambridge: Cambridge University Press, 1995); On the notion of space as a product in an of itself and therefore of the need for a theory of space see, Henri Lefebvre The Production of Space (Oxford: Blackwell Publishers, 1998)

${ }^{10}$ For a discussion of how political space is playing out in several different types of spaces at once see, Partha Chatterjee The Politics of The Governed: Reflections on Popular Politics in Most of the World (New York: Columbia University Press, 2006), in particular Chapter 2 entitled 'Populations and Political Society'

${ }^{11}$ Mezzadra, 'Citizen and Subject', note 2, p.35

12 Richard Ashley and R.B.J. Walker 'Reading Dissidence/Writing the Discipline: Crisis and the Question of Sovereignty in International Studies', Special Issue of International Studies Quarterly, Vol.34, No.3, (1990), pp.367-416

${ }^{13}$ Ibid: p.386

${ }^{14}$ Walker Inside/Outside, note 9, p.174

${ }^{15}$ Jenny Edkins and Véronique Pin-Fat 'The Subject of the Political', in J. Edkins, V. Pin-Fat and N. Persram (Eds) Sovereignty and Subjectivity (London: Lynne Rienner, 1999) pp.1-18

16 Walker Inside/Outside, note 9, p.133; See also Milič Čapek The Philosophical Impact of Contemporary Physics (London :Van Nostrand, 1961) pp.21-26

${ }^{17}$ See Pierre-Maxime Schuhl 'Le Thème du Gulliver et le postulat de Laplace', Journal de Psychologie normal et pathologique, Vol.44, No.1, (1947) p.169-184 
${ }^{18}$ Walker, 'Citizenship after', note 3; On the question of how spatial organization has influenced the evolution of political society see, for example, John Agnew 'The Territorial Trap: The Geographical Assumptions of International Relations Theory', Review of International Political Economy, Vol.1, No.1, (1994) pp.53-80

${ }^{19}$ Michael J. Shapiro 'National Times and Other Times: Re-Thinking Citizenship, Cultural Studies, Vol.14, No.1, (2000) p.79

${ }^{20}$ Walker, 'Citizenship after', note 3 (emphasis added); See also 'Sovereign Identity: The Politics of Forgetting' In: Walker, Inside/Outside, note 9, pp.159-183

${ }^{21}$ Ashley and Walker, 'Reading Dissidence', note 12, p.387; For a discussion about how this has been possible in the discipline of international relations see, for example, Roland Bleiker 'Forget IR Theory', Alternatives, 22, (1997) pp.57-85

22 R.B.J Walker and Didier Bigo 'Political Sociology and the Problem of the International', Millennium: Journal of International Studies, Vol.35, No.3, (2007) pp.725-739

${ }^{23}$ Walker Inside/Outside, note 9, p.175

${ }^{24}$ Ibid: p.129; For a discussion of how the concept of the border is playing out in unexpected ways see Nick Vaughan-Williams 'The generalised bio-political border? Re-conceptualising the limits of sovereign power', Review of International Studies, Vol.35, No.4 (2009), pp.729-749

${ }^{25}$ Jenny Edkins Trauma and the Memory of Politics (Cambridge: Cambridge University Press, 2003a), p.40

${ }^{26}$ Walker, 'Citizenship after', note 3; See also Walker 'Inside/Outside, note 9; For an account of the differences in understandings of time, space and matter between classical and contemporary physics see Čapek, The Philosophical Impact, note 16

${ }^{27}$ A 'non-national' is defined under the Irish Nationality and Citizenship Act 2001, section 2(c) as 'a person who is not an Irish citizen'. In 2001 the term non-national replaced the existing references to 'alien' which had been in Irish legislation up until that point.

28 J.M. Mancini and Graham Finlay 'CCitizenship Matters': Lessons from the Irish Citizenship Referendum', American Quarterly, 60(3), (2008) p.578

${ }^{29}$ In a European context see Liza Schuster 'Common Sense or Racism? The Treatment of Asylum Seekers in Europe', Patterns of Prejudice, Vol.37, No.3, (2003) pp.233-256; In the Irish context see, Una Crowley, Mary Gilmartin and Rob Kitchin 'Vote Yes for 'Common Sense Citizenship': 
Immigration and the Paradoxes at the Heart of Ireland's 'Céad Míle Fáilte', National Institute for Regional and Spatial Analysis (NIRSA) Working Paper Series, Vol.30, (2006) pp.1-35

${ }^{30}$ In 2004 the Irish Government specifically argued that "to become an Irish citizen a person should have a much greater connection with this country than simply being born here"- Willie O'Dea (FF) Oireachtas Debates (21 April 2004) Twenty-Seventh Amendment of the Constitution Bill 2004: Second Stage, Dáil Éireann, p.1265

${ }^{31}$ Marc Lacey 'Dominican Crackdown Leaves Children of Haitian Immigrants in Legal Limbo', New York Times, May 252008

${ }^{32}$ See, for example, Helma Lutz 'The Limits of European-ness: Immigrant Women in Fortress Europe', Feminist Review, No.57, Autumn, (1997) pp.93-111; Mancini and Finlay “Citizenship Matters', note 28

${ }^{33}$ Ronit Lentin and Eithne Luibhéid (Eds.) 'Representing Migrant women in Ireland and the EU', Special Issue of Women's Studies International Forum, Vol.27, No.4, (2004) p.301

${ }^{34}$ This residency requirement was not part of the referendum proposal itself, however, it did become part of the basis for the proposal insofar as draft legislation was prepared in tandem with the referendum proposal in order to outline how birthright citizenship would be legislated for if the referendum was passed.

${ }^{35}$ Article 2 was inserted into Bunreacht na hÉireann in 1998 as part of the Good Friday Agreement. However, it is important to note that birthright citizenship had been the practice of the state since its foundation, having been initially enshrined in Article 3 of the 1922 Constitution of the Irish Free State and later in statute (Irish Nationality and Citizenship Act 1956 and 1986) with the enactment of the 1937 Constitution, Bunreacht na Éireann.

${ }^{36}$ Michael McDowell, Oireachtas Debates (21 April 2004), Twenty-Seventh, note 30, p.1194

${ }^{37}$ The term 'Irish born children' is a term which came to be used to differentiate children born to migrant parents from children born to Irish citizen parents. Lentin argues that "the euphemism 'Irishborn children' racially differentiates the children of 'non-nationals' from all other children born in Ireland”. Ronit Lentin 'Pregnant silence: (en)gendering Ireland's asylum space', Patterns of Prejudice, Vol.37, No.3, (2003) p.310

${ }^{38}$ Lentin, 'Pregnant silence, note 36, p.301 
${ }^{39}$ Ronit Lentin 'From racial state to racist state: Ireland on the eve of the citizenship referendum', Variant, 20.2004 [Online], Available from: http://www.variant.randomstate.org/20texts/raciststate.html [Accessed 6 August 2009], p.6

${ }^{40}$ ibid

${ }^{41}$ Alana Lentin and Ronit Lentin (Eds.) Race and State (Newcastle: Cambridge Scholars Press, 2006)

${ }^{42}$ Oireachtas Debates (5 May 2004) Twenty-Seventh Amendment of the Constitution Bill 2004:

Committee Stage, Seanad Éireann, p.801

${ }^{43}$ Lobe \& Osayande v. The Minister for Justice, Equality \& Law Reform (2003), Supreme Court of Ireland Decisions [online] Available from: http://www.bailii.org/ie/cases/IESC/2003/3.html [Accessed 13 April 2010]

44 Department of Justice Equality and Law Reform, (2004a) Information Note: Proposal for Constitutional Amendment and Legislation Concerning the Issue of the Irish Citizenship of Children of Non-National Parents. p.1 [online]. Available from:

www.inis.gov.ie/en/inis/information\%20note.pdf/files/information\%20note.pdf [Accessed 13 April 2010]

${ }^{45}$ Department of Justice Equality and Law Reform (2004b) Proposed Citizenship Referendum: Article by Minister for Justice, Equality and Law Reform Mr. Michael McDowell, T.D., Published in Sunday Independent on 14 March 2004, p.1 [online]. Available from: www.inis.gov.ie/en/inis/article.pdf/files/article.pdf [Accessed 13 April 2010]

${ }^{46}$ Included among the reasons given for why women (Irish citizens and non-Irish citizens alike) could end up presenting last minute at Dublin maternity hospitals were last minute medical complications; lack of information regarding maternity care and entitlements during the nine months prior to giving birth; desire to give birth in the capital city despite having undergone anti-natal care locally and, an inability, given fears about job loss, to avail of antenatal care despite living in Ireland long-termDervla King Immigration and Citizenship in Ireland (Dublin: The Children's Rights Alliance, 2004), p.16

${ }^{47}$ Ronit Lentin, 'Strangers and strollers: feminist notes on researching migrant m/others', Women's Studies International Forum, Vol.27, Issue.4, (2004), p.305

${ }^{48}$ Lentin 'From racial state, note 39; Steve Garner 'Babies, Bodies and Entitlement: Gendered Aspects of Access to Citizenship in the Republic of Ireland', Parliamentary Affairs, Vol.60, No.3, (2007) 
pp.437-451; Lubhéid, E. (2004) 'Childbearing against the state? Asylum seeker women in the Irish Republic', Women's Studies International Forum, Vol.27, pp.335-349 - It should be noted that Garner is slightly more skeptical, however, than either Lentin or Lubhéid with regard to the ability of feminist theories when merged with racist state theories to completely 'explain' events such as the 2004 Irish Citizenship Referendum.

${ }^{49}$ On this point see, Walker, 'Sovereignties, Exceptions', note 8, p.242

${ }^{50}$ Bryan Fanning New Guests of the Irish Nation (Dublin: Irish Academic Press, 2009), p.179/180

${ }^{51}$ See, for example, Bryan Fanning 'Against the 'Racial State'. Studies: An Irish Quarterly Review, Vol. 96, No.381, (2007) pp.1-8

52 Bryan Fanning and Fidèle Mutwarasibo 'Nationals/Non-Nationals: immigration, citizenship and politics in the Republic of Ireland', Ethnic and Racial Studies, Vol.30, No.3, (2007) p.452

${ }^{53}$ Fanning, New Guests, note 50, p.148

${ }^{54}$ Ibid: p. 147

55 Ibid: p.3 It should be noted that Fanning is not advocating cosmopolitanism as a panacea for exclusion in all its various guises. He is critical of how exactly it will work. But he nonetheless sees it as the only 'real' way of ensuring that the state can successfully deal with the challenge of immigration ${ }^{56}$ Ibid: p. 149

${ }^{57}$ On the concept of the 'new Irish' see Fanning 'The 'New Irish', In: Fanning, New Guests, note 50; Alice Feldman 'The New Irish Lecture Series', Boston College Centre for Irish 48 (2007-8); Centre for the Study of Culture and Society, Conference: 'The New Irish'?, Dundalk Institute of Technology, 27 September (2007)

${ }^{58}$ Closs Stephens, 'Citizenship without' note 4, p.34

${ }^{59}$ Allen White and Mary Gilmartin 'Critical Geographies of Citizenship', Women's Studies International Forum, 31, (2008) pp.390-399; See also, for example, discussion by Piaras MacÉinrí in 'If I wanted to go there I wouldn't start from here: re-imagining a multi-ethnic nation', In: D. Ging, M.

Cronin and P. Kirby (Eds.) Transforming Ireland: Challenges, critiques, resources (Manchester: Manchester University Press), (2009) pp.38-51

${ }^{60}$ White and Gilmartin, 'Critical Geographies', note 59, p.393

${ }^{61}$ ibid; See also Gilmartin and White 'Revisiting Contemporary Irish Migration: New Geographies of Mobility and belonging', Irish Geography, Vo.41, No.2, (2009) pp.143-149 
${ }^{62}$ White and Gilmartin 'Critical Geographies', note 59, p393

${ }^{63}$ Ibid: p.394

64 ibid

${ }^{65}$ Homi Bhabha The Location of Culture (London Routledge, 1994) p.155

${ }^{66}$ Ibid: 168

${ }^{67}$ Julia Kristeva Strangers To Ourselves (New York: Columbia University Press, 1991), p.3

${ }^{68}$ Peter Nyers 'Forms of Irregular Citizenship', In: V. Squire (Ed.) The Contested Politics of Mobility:

Borderzones and Irregularity (London: Routledge, Forthcoming 2011), pp.185

${ }^{69}$ Anne McNevin 'Migrant Mobilizations in Los Angeles: Illegality, Citizenship and the City', Paper presented at the International Studies Association's Annual Convention, New Orleans, USA, (2010), pp.1-23

${ }^{70} \mathrm{McNevin}$ does not argue that this status is uncontested but that the struggles of these groups "are at once reactions to their marginalised condition and productive of new forms of political belonging... This is the kind of ambiguity that makes it possible for Felix to speak of 'undocumented citizens' and to expect that his meaning will be understood, even if the term is contested" (p.9)

${ }^{71}$ Ibid: p.4 (emphasis added).

${ }^{72}$ See also, for example, Shapiro 'National Times', note 19 who explores alternative spatio-temporal spaces of citizenship in literature and Closs Stephens 'Citizenship without', note 4 who looks at temporal disjunctures of community in design.

${ }^{73}$ Jenny Edkins 'Exposed Singularity', Journal for Cultural Research, Vol.9, No.4, (2005) p.383

${ }^{74}$ Peter Nyers 'The accidental citizen: acts of sovereignty and (un)making of citizenship', Economy and Society, Vol.35, No.1, (2006) pp.22-41

${ }^{75}$ I am very grateful to Peter Nyers for providing me with this example of the type of temporal exclusion experienced through modern concepts of birthright citizenship

${ }^{76}$ Jenny Edkins 'Humanitarianism, humanity, human', Journal of Human Rights, Vol.2, No.2, (2003b) pp. 257

${ }^{77}$ Bhabha The Location, note 65, p.7 (emphasis added)

${ }^{78}$ Shapiro 'National Times', note 19, p.85

${ }^{79}$ White and Gilmartin 'Critical Geographies', note 57, p395

${ }^{80}$ Walker, Inside/Outside, note 9, p.127 
${ }^{81}$ Rob Walker posed the question of whether a better ontology necessarily promises a better politics in his role as discussant at the panel entitled 'Vernacular Sovereignties I' at the International Studies Association's Annual Convention, New Orleans, USA, February $17^{\text {th }}$ February 2010

${ }^{82}$ Edkins Trauma and, note 25, p.xv 